2）感度補正係数は無水マレイン酸, 無水フタル酸について特 に大で，しかもピーク面積による変化が大きい。これは有機酸の 熱伝導度感度が低く, 濃度と感度とが直線関係にないことを物語 っており，ピーク面積に対応する補正法をとらねばならない。そ のため, 本定量法においては各成分のピーク面積に対応した補正 係数を図 2 から求め, ピーク面積に乗じて, 補正ピーク面積を得 て，これより定量値を算出する。

3）感度補正係数測定時に打ける標準偏差す無水マレイン酸お
よび無水フタル酸の両者は大きい。従って，これらの成分にらい ては測定值のバラッキが大きくなり易いことを示している。

4) 感度補正係数を用いて，既知試料の組成分析を行なった散 果, およびニトロベンゼンを内部標準とし，感度補正係数を併用

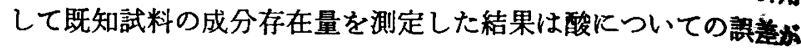
やや大きいが, 1,4-ナフトキノン, ナフタリンについては, 磼 1\% 以上で定量できた。

\title{
ビスー(2-クロルー1-ニトロソシクロヘキサン) の立体構造
}

(昭 和 40 年 6 月 4 日 受 理)

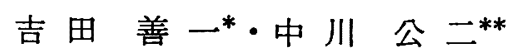

液体亜硫酸中でシクロヘキセンに塩化ニトロシルを付加させると，ビスー(2-クロル-1-ニトロソシクロヘキサン)[1] が生成する。このるのの水索化リチゥムアルミニウム還元物より［I］の立体配置を決定し，またIの赤外吸収スペクト ルよりその立体配座を決定した。

\section{1 腥 喜}

ビスー(2-クロル-1-ニトロソシクロヘキサン) [I] は 1894 年 に Baeyer1) によって合成されているが，その立体構造に関する 研究は現在までのところ皆無の状態である。そこで，著者らは U.S.P. 2, 485, 180 の方法に従い, 液体亜硫酸中でシクロへキセ ンに塩化ニトロシルを反応させることによりIを合成し，このも のの水素化りチウムアルミニウム還元物より I の立体配置を決定 し，また， I の赤外吸収スペクトルを測定し， C-Cl 伸縮振動か ら立体配座を決定することができたので報告する。

\section{2 実験}

\section{$2 \cdot 1$ 赤外吸収スペクトル測定}

赤外吸収スペクトルの 測定は日本分光回折格子型 $402 \mathrm{G}$ 赤外 分光器を用い，臭化カリウム錠剤法により行なった。波数較正は ポリスチレン膜により行なった。

$2 \cdot 2$ ビス-(2-クロルー1-ニトロソシクロヘキサン) [I] の合成 U.S.P. 2, 485, 180 の方法に従い, 液体亜硫酸 $175 \mathrm{ml}$ および

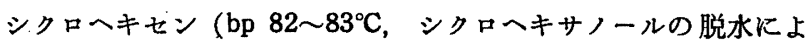
り合成 $\left.{ }^{2)}\right) 41 \mathrm{~g}$ の混合物を $-50^{\circ} \mathrm{C}$ に冷却し, これに塩化二トロ シル3) $30 \mathrm{~g}$ を 45 分間に吹込む。この温度で 3 時間かきまぜ, 生成した結晶を冾時吸引口過し, 四塩化炭素から再結晶すると, $\mathrm{mp} 137 \sim 138^{\circ} \mathrm{C}$ (分解) の結晶が得られる。収率 $76 \%$ 。

$$
\text { 分 析 值 C } 49.29 \%, \mathrm{H} 6.87 \%, \mathrm{~N} 9.35 \%
$$

* Zenichi YoSHIDA 京都大学工学部合成化学教室 : 京都市 左京区吉田.

** Koji NAKAGAWA 帝人株式会社生産技術研究所：岩国市 日出町.

1) A. Baeyer, Ann., 278, 88 (1894).

2) W. M. Dehn, K. E. Jackson, J. Am. Chem. Soc. 55, 4285 (1933).

3) H. S. Bpoth, Inorg. Synth. 1, 55 (1939).
$\mathrm{C}_{6} \mathrm{H}_{10} \mathrm{NOCl}$ としての計算值 C 48.82\%，H 6.83\%，N 9.43\% $2 \cdot 3$ 水素化リチウムアルミニウムによる [I] の還元ならひに 還元物のベンソイル化

水素化リチウムアルミニウム $1.7 \mathrm{~g}$ を脱水テトラヒドロフラン $60 \mathrm{ml}$ に溶解し, これに室温で [ I ] $2.9 \mathrm{~g}$ を脱水テトラヒドロフ ラン $100 \mathrm{ml}$ に溶解した溶液を 15 分間に滴下する。滴下後 80 分 間還流したのち放冷し, 水 $20 \mathrm{~m} l$ を加之過剩の水素化りチウムア ルミニウムを分解する。ついで， ロッシェル塩 $10 \mathrm{~g}$ 抽よ゙水酸 化ナトリウム $1 \mathrm{~g}$ を水 $60 \mathrm{ml}$ に溶解した溶液を加之, 15 分間か きませ, 連続液液抽出器を用いて, エーテルで 15 時間抽出する。 エーテル抽出液を無水炭酸カリウムで乾燥したのち, 减圧蒸留す る。 bp 74 84 ${ }^{\circ} \mathrm{C} / 17 \mathrm{mmHg}$ の留分をエーテルに溶解し, 乾燥塩 化水素ガスを吹さ込むと塩酸塩（mp 156〜 $160^{\circ} \mathrm{C}$ ) が析出する。

このアミン中には目的とする 2-クロルシクロヘキシルアミン のほかに還元的脱ハロゲン化物であるシクロヘキシルアミンがー 部含まれていることがわかったので, 精製の目的で上に得たアミ ンを常法4)に従ってベンゾイル化し，エタノール-水溶媒から再 結晶すると $\mathrm{mp} 163 \sim 164^{\circ} \mathrm{C}$ の結晶が得られた。このものは別途 合成 (2・4 に示す) したトランス-1-ベンゾイルアミノ-2-クロル シクロヘキサンとの混融結果, 融点降下を示さなかった。

$2 \cdot 4$ トランス-2-クロルシクロヘキシルアミンおよびそのベン ソイル体の合成

Paris ら5)の方法に従い, シクロヘキセンイミン (bp 50〜 51 ${ }^{\circ} \mathrm{C} /$ $20 \mathrm{mmHg}$ ) のエーテル溶液に畭燥塩化水素ガスを吹込み, トラン スー2-クロルシクロヘキシルアミン塩酸塩 $\left(\mathrm{mp} \mathrm{214} 215^{\circ} \mathrm{C}\right)$ を 合成した。

4) R. L. Shriner, "The Systematic Identification of Organic Compounds", John Wiley \& Sons, Inc., New York (1956) p. 226.

5) O. E. Paris, P. E. Fanta, J. Am. Chem. Soc. 74, 3007 (1952). 
分析 值 C $42.19 \%, \mathrm{H} 7.61 \%, \mathrm{~N} 8.12 \%$ $\mathrm{C}_{6} \mathrm{H}_{13} \mathrm{NCl}_{2}$ としての計算值 C $42.37 \% ， \mathrm{H} 7.70 \%, \mathrm{~N} 8.24 \%$ これを, Shriner4) の方法でベンゾイル化して、トランス-1-ベ

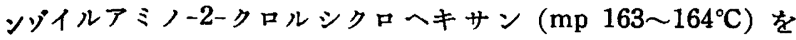
得た。

分 析 值 C $65.43 \%, \mathrm{H} 6.59 \%, \mathrm{~N} 5.85 \%$ $\mathrm{C}_{18} \mathrm{H}_{16} \mathrm{NOCl}$ としての計算值 C $65.68 \% ， \mathrm{H} 6.79 \% ， \mathrm{~N} 5.89 \%$ 2.5 シス-2-クロルシクロヘキシルアミンおよびそのベンソイ ル体の合成

Mc Casland $5^{6)}$ の方法に従い, トランス-2-アミノシクロへキ サノール $\left(\mathrm{mp} 62 \sim 64^{\circ} \mathrm{C}\right)$ に五塩化りンを作用させて，シス-2-ク ロルシクロヘキシルアミン塩酸塩 $\left(\mathrm{mp} 201 \sim 202^{\circ} \mathrm{C}\right.$ ) を合成した。 分 析 值 C $42.63 \%, \mathrm{H} 7.89 \%, \mathrm{~N} 8.22 \%$ $\mathrm{C}_{6} \mathrm{H}_{18} \mathrm{NCl}_{2}$ としての計算値 C $42.37 \% ， \mathrm{H} 7.70 \% ， \mathrm{~N} 8.24 \%$ これを常法4)でベンゾイル化して，シス-1-ベンゾイルアミノー

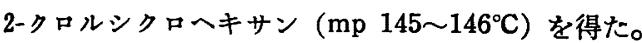

分 析 值 C $65.50 \%, \mathrm{H} 6.68 \%$, N $5.86 \%$ $\mathrm{C}_{18} \mathrm{H}_{16} \mathrm{NOCl}$ としての計算値 C $65.68 \% ， \mathrm{H} 6.79 \% ， \mathrm{~N} 5.89 \%$

\section{3 結 果 と 考 察}

臭化カリウム錠剤法による [ I ] の赤外吸収スペクトル測定結 果を図 1 に示す。

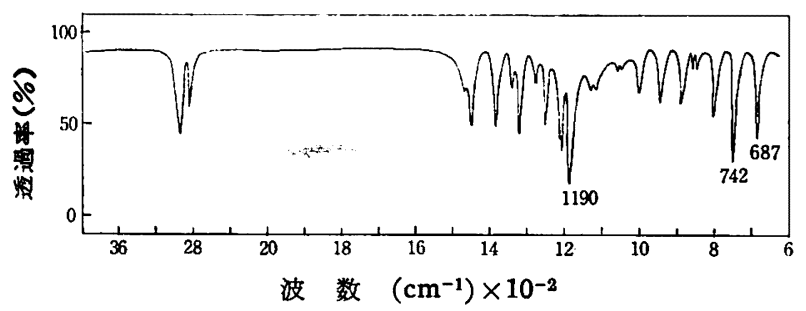

叉 1 ビスー(2-クロルー1-ニトロソシクロヘキサン) の赤外吸収スペクトル

この罒にみられるように，C-Cl 伸縮振動として $742 \mathrm{~cm}^{-1}$ と $687 \mathrm{~cm}^{-1}$ の二つの吸收帯が存在する。シクロヘキサン誘導体で はエカトリアル C-Cl は 736〜856 $\mathrm{cm}^{-1}$ に, アキシアル C-Cl は $646 \sim 730 \mathrm{~cm}^{-1}$ に伸縮振動を示すことがよく知られている7の で, 前者はエカトリアル $\mathrm{C}-\mathrm{Cl}$ 伸縮振動に, 後者はアキシアル C-Cl 伸縮振動に㷌属できる。

つぎに，トランス-1,2-ジ置換シクロへキサンにおいて，優位 立体配座はエカトリアル型であると考えられる。実際に，トラン スー1, 2-ジメチルシクロヘキサンは室温でほとんど完全に (99\%) エカトリアル型で存在する ${ }^{8)}$ 。これに反し, シス-1,2-ジ置換シク ロヘキサンではいずれか一方の置換基が不安定なアキシアルの位 膡をしめなければならないので，両置換基の空間的大きさが余り 変わらない場合は $(\mathrm{a}, \mathrm{e}) \rightleftharpoons(\mathrm{e}, \mathrm{a})$ の平衡にあると思われる。

I の赤外吸収スペクトルはアキシアル C-Cl 抽よ゙ェカトリア ル C-Cl の両伸縮振動を有するので，一見シクロヘキセンに塩化

6) G. E. Mc Casland, R. E. Clark Jr., H. E. Carter, J. Am. Chem. Soc. 71, 637 (1949).

7) D. H. R. Barton, "Some Recent Progress in Conformational Analysis, Experimentia" Suppl. II, 121(1955).

8) E. L. Eliel, "Stereochemistry of Carbon Compounds" Mc Graw-Hill (1962) : p. 211.
ニトロシルがシス付加している上5に思われる。テトラヒドロフ ラン中水素化リチウムアルミニウムによるI の還元は実験の部に 示したようにトランス-2-クロルシクロヘキシルアミン（とシク ロヘキシルアミン) を与え, シス-2-クロルシクロヘキシルアミ ンは全く得られなかった。これはIの還元物のベンソ゚イル体と別 途合成品との混融試験のほか I の還元生成物の塩酸塩の赤外吸收 スペクトル測定の結果, その $\mathrm{C}-\mathrm{Cl}$ 伸縮振動はエカトリアル $\mathrm{C}-\mathrm{Cl}$ に帰属できる $938 \mathrm{~cm}^{-1}$ にあり，アキシアル C-Cl に㷌属できる $692 \mathrm{~cm}^{-1}$ には全く吸収がなかったことから明白である。参考ま でに別途合成したトランスおよびシス両 2-クロルシクロヘキシ ルアミン塩酸塩の赤外吸収スペクトルを図 2 および因 3 に示す。

図にみられるように，C-Cl 伸縮振動は，トランス体では 738 $\mathrm{cm}^{-1}$ に, シス体では $692 \mathrm{~cm}^{-1}$ にみられる。

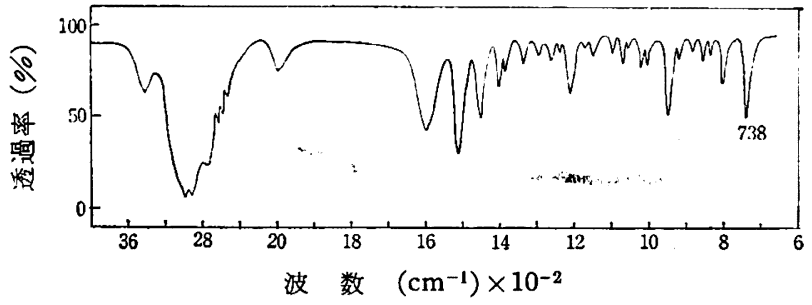

图 2 トランス-2-クロルシクロヘキシルアミン塩酸塩 の赤外吸収スペクトル $(\mathrm{KBr}$ 鋐剤)

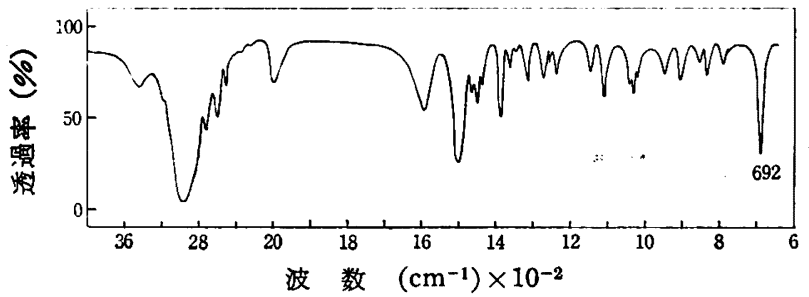

図 3 シス-2-クロルシクロヘキシルアミン塩酸監 の赤外吸収スペクトル（ $\mathrm{KBr}$ 錠斉）

ニトロソ基がアミノ基 に還元されるさい，立体 配直が反転することは考 えられぬので, 上の事実 からニトロソ基とクロル 原子はトランスの立体配 置を有するものと結論さ れる。

また，Iの赤外吸収ス ペクトル（因1）に扰い て、トランスニトロソダ イマーの特性吸収位置で ある $1190 \mathrm{~cm}^{-1}$ に吸収 が認められるから，ダイ マーの立体配直はトラン スであることがわかる。
[A]

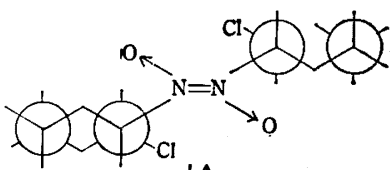

[B]

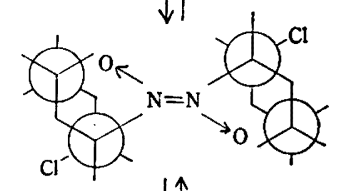<smiles>[C+]1=CC=C1</smiles>

[C]

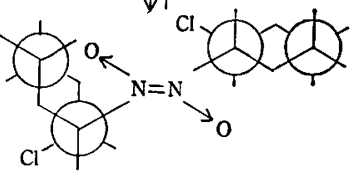

四 4 ピスー(2-クロル-1-ニトロソシ クロヘキサン) の立体粠造
以上のことがらから，I の立体構造は図 4 亿示すように [A], [B], [C] の 3 種のコンホーマーが平衡の状態にあるものと推 定される。

$687 \mathrm{~cm}^{-1}$ のアキシアル C-Cl の伸縮振動の吸収強度と $742 \mathrm{~cm}^{-1}$ のエカトリアル C-Cl の伸縮振動の吸收強度より考え，[A] 括 
よび [B] の存在割合は 1.4:1 程度と考兄られる※1。一般に， ジアキシアル型は 1,3-ジアキシアル相互作用のため不安定と考

※1 エカトリアルおよびフキシフル両 $\mathrm{C}-\mathrm{Cl}$ 伸縮振動吸収帯の 分子吸光俰数には大差ないるのとし, 両吸収帯に base line 補正を行なった上で、両者の吸収強度 $\log \left(I_{0} / I\right)$ から [A] および [B] の存在割合を算出した。
えられるが，Iにおいてはジアキシアル型とジェカトリアル型と の安定性にはあまり差がないよ5に思われる。このことは, ジェ カトリアル型に拈いてはクロル原子とニトロソ基が近距離に存在 するため, 両置換基間に静電的反発作用が働き，比較的不安定に なるためとして説明される。

\title{
イソシアナート・マロン酸ジエステル付加体の熱分解反応†
}

(昭 和 40 年 6 月 22 日受理)

阿河利男・南敦・小森 三 郎*

\begin{abstract}
イソシフナート・マロン酸ジェステル付加体の熱分解反応を行なったところ, 脂肪族インシフナート・マロン酸ジス テル付加体 (UI) は従来から認められているよ5にインシアナートとマロン酸シェステルに熱分解することが認められた が, 芳香族イソシフナート・マロン酸シェステル付加体 (I ) は挀点付近の分解反応では, 芳香族イッシフナートとマロ ン酸シェステルヘの分解がほとんど認められず, メタントリカルボン酸トリフニリド（II）やメタントリカルボン酸エス テル（III）の生成が認められ，I の熱分解反応は，ヶテン中間体を通って進行していると考えられ，従来の熱分解反応と は異なることを見出した。
\end{abstract}

\section{1 腥言}

イソシアナートはカルボン酸, ポリオール, ポリアミン等活性 水素を持つ物質と反応して，ポリアミド，ポリウレタン，ポリウ レア等を生成し，織維、フォーム，塗料等として大きな用途を持 っている。イソシアナートの反応性の大きいことは，これらの用 途に対しては非常に重要であるが，一方，空気中の湿気と反応し て尿素誘導体を作り易く，保存が困難な欠点がある。この欠点を 解消するために, イソシアナート活性水素付加体が考えられた。 これは式（1）のように熱, 触媒で分解してイソシアナートを再 成する。

$$
\mathrm{RNCO}+\mathrm{HR}^{\prime} \underset{\mathrm{m}}{\rightleftarrows} \mathrm{R} \mathrm{i}^{\mathrm{H}} \mathrm{COR}
$$

この活性水素物質には,フェノールが主として使われているが， 分解温度は $150^{\circ} \mathrm{C}$ を必要とすること, アミノ基が存在すると常温 で分解すること, フェノールの臭気が強い等の点で, その使用に 制限がある2)。前報において著者らは，各種アルコールによるイ ソシアナートのブロック体と分解温度の関係を報告した1)。その
際マロン酸ジェステルもブロック体を与える。しかもその分解温 度は低く，非常にブロック試薬として適していると考えられたが， ブロック体をポリオールと共にガラス板上に塗布して，加熱した ところ他のアルコール類と異なり, 高い硬度の塗膜を与えなかっ た。その原因について追求し，式（1）とは異なる反応が起きて いること,イソシアナートは生成せず, メタントリカルボン酸ト リアニリド，メタントリカルボン酸エステルが生成することを確 認したので，その結果について報告する。

\section{2 实 験 結 果}

$2 \cdot 17$ フルイソシアナート・マロン酸ジエステル付加体の 熱分解反応

フェニルイソシアナート・マロン酸ジェステル付加物（メタン トリカルボン酸ジメチルエステルアニリド（（ａ）およびメタン トリカルボン酸ジエチルエステルアニリド（Ｉｂ）を減圧下種々の 温度で熱分解した結果を表 1に示した。これらの分解反応におい ては高温度では従来から報告されまた一般に認められているイソ シアナート発生剤としての役割を果すが, 融点付近で分解反応を

表 1 フェニルイソシアナート・マロン酸シェステル付加体の熱分解

\begin{tabular}{|c|c|c|c|c|c|c|c|c|c|c|}
\hline \multirow{2}{*}{ No. } & \multirow{2}{*}{ 試料 } & \multirow{2}{*}{$\begin{array}{c}\text { 武料量 } \\
(\mathbf{g})\end{array}$} & \multirow{2}{*}{$\begin{array}{c}\text { 反庆㳑度*2 } \\
\text { (C) }\end{array}$} & \multirow{2}{*}{$\begin{array}{c}\text { 反応時間 } \\
(\mathrm{hr})\end{array}$} & \multirow{2}{*}{$\begin{array}{c}\text { 娍压度 } \\
(\mathbf{m m H g})\end{array}$} & \multicolumn{2}{|c|}{ 生 } & \multirow{2}{*}{$\overbrace{N^{* 3}}^{\text {成 }}$} & \multicolumn{2}{|l|}{ 物*1 } \\
\hline & & & & & & II & $\mathrm{III}^{* 3}$ & & $V^{* 4}$ & VI \\
\hline \multirow[t]{2}{*}{1} & I a & 3.00 & 100 & 4 & 3 & $\begin{array}{c}0.53 \mathrm{~g} \\
(1.42 \mathrm{mmol})\end{array}$ & $\begin{array}{c}0.41 \mathrm{~g} \\
(2.16 \mathrm{mmol})\end{array}$ & - & - & - \\
\hline & I a & 5.05 & 130 & 2.5 & 3 & コン跡 & $0.04 \mathrm{~g}$ & コン跡 & コン跡 & $2.77 \mathrm{~g}$ \\
\hline 3 & I b & 3.00 & 125 & 2 & 3 & $\begin{array}{c}0.62 \mathrm{~g} \\
(1.67 \mathrm{mmol})\end{array}$ & $\begin{array}{c}0.66 \mathrm{~g} \\
(2.84 \mathrm{mmol})\end{array}$ & コン跡 & コン跡 & コン赫 \\
\hline 4 & I b & 4. 20 & 150 & 1 & 3 & コン跡 & $\begin{array}{c}0.17 \mathrm{~g} \\
(0.73 \mathrm{mmol})\end{array}$ & $\begin{array}{c}0.77 \mathrm{~g} \\
(4.81 \mathrm{mmol})\end{array}$ & $\begin{array}{c}0.44 \mathrm{~g} \\
(3.72 \mathrm{mmol})\end{array}$ & $1.58 \mathrm{~g}$ \\
\hline
\end{tabular}

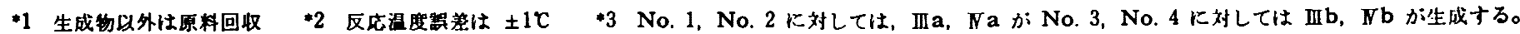
*4 ジフェニル尿就として定量

$\dagger$ この報文を「ウレタン塗料に関する研究（第 5 報)」とす ろ.

* Toshio Agawa, Tōru Minami, Saburo KomoRI 大阪 大学工学部応用化学科：大阪市都島区東野田。
1）阿河, 服部, 園山，小森，色材協会誌 38，465 (1965).

2)たとえばJ.H. Saunders, et al., “Poly urethanes I”, John Wiley, New York (1962), p. 120 ; G. Griffin et al., Ind. Eng. Chem. Prod. Res. 1, 265 (1962). 